\title{
On the Effectiveness of Strengthening Teachers' Morality Construction in Chinese Higher Vocational Colleges
}

\author{
Chen Rui \\ Chongqing Vocational College of Applied Technology, Hechuan District, Chongqing \\ 401520, China
}

\begin{abstract}
Since ancient times, the duty of teachers has been to teach and educate people, which requires teachers not only to have excellent professional skills, but also to have noble moral character, otherwise they can not achieve the purpose of educating people if there is a problem with teachers' ethics. In the past, higher vocational colleges have paid more attention to teachers' professional ability, but not too much attention to teachers' ethics, and with the development of society, the demand for talents with excellent academic qualities is increasing, which requires teachers to develop in both ways The school must focus on strengthening the construction of teachers' ethics. This paper will discuss how to further strengthen the construction of teachers' ethics in colleges and universities.
\end{abstract}

Keywords: Higher vocational colleges; ethics construction of teachers; effectiveness; measures

\section{Introduction}

Teachers play an irreplaceable role in the process of everyone's growth. Teachers not only teach students knowledge, but also play an important role in shaping students' values and outlook on life. Teachers' thinking depth and moral level will be shown in words and deeds. Teachers have always been noble in the eyes of the public, but in recent years, the child abuse in Shanghai kindergartens and

https://doi.org/10.47852/bonviewCETR2020010232

This is an open access article published by the BON VIEW PUBLISHING PTE. under the Creative Commons Attributions License. 
tuberculosis in Tao jiang County, Human Province have reminded us of the necessity of the construction of teachers' ethics.

\section{Importance of the Construction of Teachers' Ethics}

1. It is conducive to have a better conduct of "building up people by virtue"

Since the 18th National Congress of the Party, we have regarded "who to cultivate people, what kind of people to cultivate, how to cultivate people" as the fundamental problem of the development of our country's Congress has been opened, it is still the fundamental task of our country's education to build up people by virtue.That is to say, in the process of imparting knowledge to students, teachers should also tell students what kind of people they should become and what kind of moral character they should cultivate. This requires that teachers' own values are correct enough to guide students and make the truth more persuasive. Furthermore, it is not only the moral of students, but also the moral of teachers. Therefore, strengthening the construction of teachers' ethics in higher vocational colleges is conducive to higher vocational colleges better respond to the national call and better practice the ${ }^{[1]}$ of "building up people by virtue" of virtue.

2. It is beneficial to influence students to establish correct values and outlook on life.

Students in higher vocational colleges are in the critical period of the formation of values and outlook on life. They have experienced intense learning and strict school management in high school. Especially the development of network and the popularization of smart phone make students receive a lot of mixed information and values in a short time. If teachers can not guide students in time, many students may indulge in online games because of their poor self-control, do not want to learn, and may set up false values such as money worship and hedonism under the influence of the network. On the one hand, teachers can know how to guide students, on the other hand, they can strengthen their own ideological and moral construction, thus affecting teachers' words and deeds. Let teachers in the longterm process of getting along with students with words and deeds slowly affect students, set a good role model, so as to fundamentally affect the formation of students' correct values and outlook on life.

\section{Problems existing in the ethics of teachers in higher vocational colleges}

\section{Problems in educational thought}

Not all teachers have a high degree of love and dedication, many higher vocational teachers choose to be higher vocational teachers, including the stability of their work and winter and summer vacation, but also the high social status of teachers, but not love the education industry, Plus higher vocational teachers have plenty of time at their disposal. As a result, many higher vocational teachers do not focus on teaching and educating people in their daily work, but on earning money in part-time jobs. It can be said that many teachers themselves have a very serious phenomenon of money worship. 
Many teachers will use their time to open online stores, do micro-business, or strive to improve their readiness to change jobs. As a result, teachers simply do not have enough energy to think about how to teach, and even make use of the convenience of teachers' duties to promote their own "business" to students, which has a very negative impact on of students.

\section{Stagnant teaching capacity}

Under the guidance of such values, teachers can not focus on improving their teaching ability, and many teachers will not prepare lessons carefully. Most of them rely on their own experience to play in the classroom. For some old professors, there is nothing wrong with this way of preparing lessons. Because of the teaching experience, these teachers have already understood the teaching content very well and explained it very skillfully, and some teachers with poor ability also do not prepare lessons well. As a result, the teacher's thinking is not clear and the content is not coherent in the course of the lecture, which affects the students' listening experience very much. Students can feel that the teacher's attitude is not serious and the professional ability has problems, which not only leads to the students' reluctance to listen, but also the school management.

\section{Lack of teachers' awareness of educating people}

Many teachers think that as long as they are responsible for the professional knowledge and skills of students, they will not communicate some morality and values, and teachers' awareness of educating people is insufficient. Many teachers find that there are some problems in students' thoughts and ideas in class, but ignore them.

\section{Strategies for the Construction of Teachers' Ethics in Higher Vocational Colleges}

The construction of good teacher ethics is not only a long-term process, but also requires the joint efforts of the whole society, especially the state, schools and teachers must play their respective roles, in addition, students and the public should play their own supervisory role.

1. The State shall establish and improve laws and regulations relating to the construction of ethics and demeanour of teachers

In order to strengthen the construction of teachers' ethics in higher vocational colleges, the state should first pay more attention to the construction of teachers' ethics, establish and perfect the relevant laws and regulations of the construction of teachers' ethics, and provide system guarantee and guidance for the construction of teachers' ethics.At present, China has a series of laws and regulations on the construction of teachers' ethics, such as Code of Professional Ethics for Teachers, Compulsory Education Law of the People's Republic of China and the newest Training Plan for Teachers of Ideological and Political Theory Course in Colleges and Universities, Can provide system guarantee for the construction of teachers' ethics. During the construction of teachers' ethics, schools can combine these systems to ensure the scientific and rational ${ }^{[3]}$ of teachers' ethics construction. 
2. Creating a good Social Atmosphere of Ethics and ethics of teachers

The social environment and atmosphere can greatly affect the quality of the construction of teachers' ethics. The construction of teachers' ethics in higher vocational colleges is not only beneficial to the students of higher vocational colleges, but can have a positive impact on the whole society. Therefore, the whole society should do its part for the construction of teachers' ethics, create a good atmosphere for the construction of teachers' ethics, and provide a favorable social environment for the construction of teachers' ethics in schools. In this process, the media can play an important role, with the development of network information technology, we ushered in the new media era, now everyone can become content creators and disseminator of content, some influential self-media should play their own role, the mainstream media can strengthen the reporting of noble teacher ethics events, thus causing the whole society to pay attention to teachers' moral character and style, under the attention of the whole society, let teachers strengthen their own ideological disorder, strengthen their own teacher ethics construction, for serious teacher ethics events, the media should also strengthen exposure, so as to avoid some teachers do not attach importance to their own and teacher style Teachers' ethics and correct teachers' teaching attitude.

3. Higher vocational colleges should improve their own efforts to build teachers' ethics.

3.1 Strengthening organizational leadership mechanisms

Strengthening the organizational leadership mechanism can make the construction of teacher ethics more scientific and efficient. For this reason, the school can let the school party committee take charge of this work, and the main cadres of the party committee should give full play to their own functions and powers.Schools can also build special leading groups for the construction of teachers' ethics, let special people manage the ethics of teachers, put work responsibilities into place, avoid empty talk slogans, but lack of special personnel to be responsible for the phenomenon. At the same time, it also provides guidance ${ }^{[4]}$ for teachers who do not know how to strengthen their own ethics.

\subsection{Strict access control for higher vocational teachers}

In the past, when recruiting teachers, higher vocational colleges often only assess teachers' teaching ability, but ignore the assessment beyond professional ability. It is necessary to know whether a person is suitable for being a teacher is not only related to professional ability, but also related to his inner thoughts, values and moral accomplishment, although most files show no moral stains. But it is likely that "there are no big mistakes, small mistakes continue to ", but these small mistakes are likely to lead to teachers in the long-term teaching process to adversely affect students, so the school in the process of teacher recruitment in addition to the assessment of teachers' professional quality. After teachers enter the post, they should not only provide teachers with teaching training, but also provide new teachers with teacher ethics training. Excellent professional ability teachers can be constantly honed through teaching practice. Moral quality and professional attitude are influenced by many factors 
for a long time. Colleges and universities must strictly control ${ }^{[5]}$ when recruiting teachers.

3.3 Establish and improve the reward and punishment mechanism for teachers

The establishment of a sound reward and punishment mechanism can play a very good supervisory role, in fact, because everyone's growth environment and contact with things are different, everyone's values, outlook on life and morality are different, some extremely wrong ideas will certainly lead to a person's teacher ethics problems, and because of the natural characteristics of profit, some ideological deviations can be tolerated, as long as the supervision work, most teachers will not have serious problems of teacher ethics. Therefore, the school must guide the teacher's behavior through the perfect reward and punishment mechanism, so that the teacher can do the work of teaching and educating people even out of the instinct of profit. Schools can mobilize all students to reflect the problems existing in the group of teachers, can establish channels for students to reflect WeChat, Weibo and so on, but the school must find out the problems raised before dealing with them.

4. Higher vocational teachers should attach importance to the construction of teachers' ethics

4.1 Teachers should correct their teaching attitude

A good teacher's ethics must include a teacher's own correct teaching attitude. Therefore, on the one hand, teachers should make clear that their duties include teaching and educating people. On the other hand, of teaching and educating people in the process of teaching. With the increase of teaching time, teachers' teaching ability can be improved through the accumulation of teaching experience, and whether teachers' teaching attitude is serious or not, whether running a school is rigorous determines the speed of improving teachers' teaching level.For this reason, teachers must pay attention to the summary of experience in teaching work, constantly learn to improve their own knowledge, arm themselves with knowledge, so as to improve their professional quality and teaching ability. At the same time, some values should be interspersed in the teaching process to influence students with knowledge and personality charm, so as to achieve the ${ }^{[6]}$ of teaching and educating people.

\subsection{Teachers love their jobs}

The strengthening of teachers' moral construction requires teachers to love and work hard. Only when teachers love their jobs can they devote most of their energy to education and teaching, and they will be full of professional happiness and professional pride. Then at least to work hard, whether a person is responsible enough. Therefore, although higher vocational teachers can freely arrange their leisure time, teachers should not put too much energy on things that have nothing to do with the cause of teachers, let alone use their influence among students to "do business ". For some teachers with strong desire for money, at least do their own work and do other work ${ }^{[7]}$.

\subsection{Teachers should consciously guide students' values}

Under the influence of market economy, the current social atmosphere of money worship and 
hedonism is more serious. Therefore, teachers should use ideological and political knowledge to arm themselves and convey correct values to students. Avoid high school colleges and universities to cultivate "exquisite egoists ", so that society more and more indifferent.

\section{Conclusion}

To sum up, with the development of economy and social progress, it is becoming more and more important to strengthen the construction of teachers' ethics in higher vocational colleges, and the state, society, schools and teachers themselves should deal with this, so that the education cause of our country can get better development.

\section{Acknowledgement}

This work is supported in part by Foundation project: Research on Teachers' Professional Identity in Higher Vocational Colleges from the Perspective of Moral Education in the New Era (20SKGH359)-Humanities and Social Sciences Research Project of Chongqing Education Commission in 2020.

\section{References}

[1] Liu Yi. Discussion on the Present Situation and Countermeasures of Teachers' Ethics and Ethics in Higher Vocational Colleges in J]. New Era Global Market ,2018,(24):270-270.

[2] Zhang Chenchen, Wang Lili. A Study on the Construction of Young Teachers' Ethics and Ethics in Higher Vocational Colleges in the New Era Journal of Tianjin Vocational College ,2019,21(4):77-80.

[3] Zhang Chenchen, Wang Lili. A Study on the Construction of Young Teachers' Ethics and Ethics in Higher Vocational Colleges in the New Era Journal of Tianjin Vocational College ,2019,21(4):77-80.

[4] Qiu Tao. A Some Reflections on Strengthening the Construction of Teachers' Ethics and Ethics in Higher Vocational Colleges [J].]; and Technology Information ,2019,17(8):202 204

[5] Zhuang Baipeng, Tan Jintian. A Study on the Construction of Young Teachers' Ethics and Ethics in Higher Vocational Colleges in the New Era Modernization of education ,2018,5(29):108-109.

[6] Ren Yanhua. A Study on the Construction of Teachers' Ethics and Ethics in Ideological and Political Colleges in Higher Vocational Colleges in J]. New Period Science and Technology Economic Guide 2018(18):157-157.

[7] Liu Yanxia. A Study on Effective Strategies to Promote the Construction of Teachers' Ethics and Ethics [J].] Solid and Effective Study Weekly ,2019,385(1):151-152. 